\title{
Effects of Globalization on National Competitiveness of Entrepreneurs: Opportunities and Threats ${ }^{*}$
}

\author{
M. Hakan Yalçınkaya, Coşkun Çılbant, Neslihan Yalçınkaya, İsmet Güneş \\ Celal Bayar University, Manisa, Turkey
}

\begin{abstract}
Predominant role of outsourcing strategy toward technological development and competition in globalization should not be ignored. This competitive process makes especially the nation states that started to undergo liberalization process recently and their sectors and/or firms to adapt to and use innovations in order to survive. The competition for countries can only be a type of incorporation's place for competition. A country's competitiveness depends on factors such as the level of sophistication and productivity of R\&D (research and development) activities, performance of the various sectors, country's foreign trade surplus, production of goods that have high-tech characteristics, and availability of skilled and experienced manpower. Some economists advocate that the competitiveness of a national economy is a macro-economic phenomenon, so it is determined by factors such as interest rates, exchange rates, and budget deficits. Similarly, some economists advocate that the competitiveness can be achieved with cheap and abundant labor force. This study will discuss entrepreneurs' problems in enhancing the competitiveness, which becomes more important because of globalization, and precautions to be taken to reduce or completely eradicate these problems, at micro- and macro-economic levels.
\end{abstract}

Keywords: globalization, competitiveness, entrepreneurship

Increasingly intensive economic, political, and cultural relations between countries, mutual interaction of different cultural and social structures within societies, and the collapse of the Cold War walls resulted in globalization. One should also keep in mind the significant role of technological development and competition oriented international trade expansion in the world economy's globalization. Generally speaking, foreign trade policies, financial policies, and economy policies of developed and developing countries form the basis of the globalization.

Although many strategists claim that "globalization" is the most frequently discussed phenomenon of our time, came to an end with the September 11 attacks, its impact on every aspect of life, from communal living to

\footnotetext{
${ }^{*}$ This is the full text of the paper presented at the 6th International Congress on Entrepreneurship in Bishkek on April 24-26, 2014.

Corresponding author: M. Hakan Yalçınkaya, Ph.D., assistant professor, Department of Economy, Faculty of Economics and Administrative Sciences, Celal Bayar University; research fields: SMEs (small and medium-sized enterprises), competitiveness, and globalization. E-mail: mustafahakanyalcinkaya@gmail.com.

Coşkun Çılbant, Ph.D., assistant professor, Department of Economy, Faculty of Economics and Administrative Sciences, Celal Bayar University; research fields: sector analysis and analysis of investments. E-mail: coskun.cilbant@cbu.edu.tr.

Neslihan Yalçınkaya, Ph.D., instructor, Department of Management, Saruhanlı Vocational School of Higher Education, Celal Bayar University; research fields: marketing, competition, and political marketing. E-mail: neslihanyalcinkaya@hotmail.com.

İsmet Güneş, Ph.D. candidate, research assistant, Department of Economy, Faculty of Economics and Administrative Sciences, Celal Bayar University; research fields: finance and the efficiency of banks. E-mail: ismet.gunes@cbu.edu.tr.
} 
economy, continue. Rapid change and development in communication technologies cause globalization to become deeper, and deep globalization forces a more intense competition climate.

When we look at the situation from developing countries' point of view, finding your place and gaining competitiveness in globalization depends on manufacturing either high quality and branded goods and services, or joining a regional integration.

The increasing importance of liberal thinking along with the Industrial Revolution, the development of an economic system called "market economy", and removal of borders impacted basic macro-economic indicators of countries in a faster and deeper manner.

\section{Conceptual Approach to Globalization}

Globalization, one of the most debated and also most popular phenomena of our time, is a result of a transition period from industrial society to information society in the whole world, and has intertwined with infrastructures of economic, political, and cultural concepts, and has impacted every aspect of life.

Philosophers such as Muray Rohtbard and David Friedman, who are considered as conceptual fathers of "globalization", put "free market principle" into the hearth of their works since the 1970s. According to the definition made by Friedman, "globalization" is a process comprising substantial integration of markets, nation states, and technologies. It is a dynamic process that provides easier, faster, and cheaper reach for individuals, companies, and nation states to every part of the world. Globalization is not a temporary tendency. On the contrary, it is an inclusive international system that shapes domestic politics and external relations of almost every country, and it has sui generis characteristics (Friedman, 2000, p. 31).

David Held and Anthony McGrew define globalization as "a process that builds inter-continental or inter-regional flows and networks and that represents transition in spatial organization of social relations" (Kürkçü, 2013, p. 2).

On the other hand, Bauman uses positive and negative aspects of the concept when analyzing and defining "globalization" from a different point of view: According to Bauman, globalization occurs during the redistribution process of privileges and deprivations, of wealth and poverty, of resources and impotencies, of power and powerlessness, and of freedom and constraints (Bauman, 1999, p. 81).

\section{Three Dimensions of Globalization}

It is possible to analyze globalization in three dimensions, namely economic, political, and cultural, in terms of the areas that it affects (Demirel, 2006, pp. 107-109).

Economic globalization is considered as integration of national economies with world markets and determination of all economic decision processes in accordance with the capital accumulation dynamics of the global capitalism (Yeldan, 2001, p. 14). Economic globalization in reality reveals the effectiveness of capitalist organizational logic of free market economy and indicates the wealth reached by the Western capital circles, which are prevalent in the capitalist organizational logic (Aktel, 2003, p. 57). This process brings economic integration phenomenon along as well. In the end, it causes the neo-liberal policies, which aim to establish an economy suitable to the needs and demands of multinational capital, to find an ever-expanding practice area (Doğan, 2002, p. 33). This concept comprises good and factor movements without any inhibition and equalization of players in the market in terms of opportunities in competition, and explains the globalization of production, finance, and trade (Bayraktutan, 2003, pp. 146-147). 
Globalization from political point of view requires re-shaping relations and roles among state, society, and individual, and creates an increase in democratization axis together with supranational mechanisms in face of nation state in use of initiative for civil society. The effort of European Union (EU), which have completed various steps of economic integration since 1950 s, to create a conventional and institutional federative and united Europe is a good example of the fact that political globalization cannot be achieved solely by nation states and that it requires some regional union (blocks) and supranational integration efforts as well. Political globalization also helps democracy understanding, which already has hard time explaining itself because of a representative mechanism in homogenization axis within nation state, to assume a more participative color.

Cultural globalization tendency makes the problems, discussions, and solutions of societies common (Aktel, 2003, p. 60). In cultural globalization, there is an emphasis on co-existence of different cultures under the light of multi-partite characteristics based on post-modern rhetoric and, in a sense, on social contract's re-implementation and de facto implementation. Rapid developments in transportation and communication networks create multi-culturalism and a cultural variety in nation states. Differences among cultures decrease and common reactions against many issues (democratization, human rights, rule of law, environment, war, and natural disasters) occur. The negative impact of cultural globalization, on the other hand, is the threat that economically dominant developed countries' values will erode local cultural mosaics and traditions, and lead to an imitator cultural degeneration in developing or underdeveloped countries. As a result, globalization causes geographical borders to be more than an element dividing states from each other with its definition and dimensions (Sezen, 1999, p. 60).

In this day and age, world economy's current state, which gained importance with the globalization, is a climate of uncertainty caused by efforts of rapid and effective restructuring in economic activities. Globalization results in rapid dissemination of a change in any corner of the world, whether positive or negative, to the other parts of the world. Our world is becoming increasingly complex and unsteady (Eren, 2004, p. 262). As a result of this, in this era, it becomes vital to produce new strategies and develop new policies for the countries that open up their economy and aim to integrate with the world economy, because globalization in manufacturing, trade, and finance sectors continue, and money, capital, and good movement liberalization knows no boundaries (Gündüz, 2005, p. 199). Because globalization causes changes in the field of activity, productions, competition styles, and management understanding of firms, it obliges firms to compete against global competitors in a global market, instead of competing in only their own domestic market and at a very limited international level (Egeli, 2009).

Societies, which benefit from integrating their economies with the world economy, are societies that trigger mutual economic dependency that can manage social and politic discussions, and that have necessary supplementary institutions. From the globalization point of view, judging from previous experiences of countries, what is important is not whether a country is globalized or not, but rather how it globalized. World markets are sources for economic growth and welfare as much as for crises and fluctuations. Without effective management, justice, civilian and political rights, freedoms, necessary and supplementary institutions in social security and education, the countries mostly import turmoil, chaos, and crises from world markets (Gökbunar \& Yanıkkaya, 2004, p. 26).

\section{Globalization and Competitiveness}

National competitiveness has become the fundamental topic of the governments and industrial institutions 
in every country. Competitiveness can be defined as "relative industrial efficiency and relative cost superiority' of an industry or firms that compose an industry, which develops depending on the quality, cost, rapid delivery, marketing power, financial strength, and the work environment" (Ertürk, 1996, p. 208). Table 1 shows the definitions of competitiveness.

Table 1

Definitions of Competitiveness

\begin{tabular}{|c|c|}
\hline Author/Institution & Definition \\
\hline Industrial Competition Commission & $\begin{array}{l}\text { Competitiveness is the capability and success of a country in presenting its products and } \\
\text { services to international markets while trying to increase the real income of its citizens } \\
\text { under free and established market conditions. }\end{array}$ \\
\hline Scoot and Lodge & $\begin{array}{l}\text { It is the capability of countries to manufacture and distribute their products and services that } \\
\text { could be directed to international trade while increasing their own gains from their own } \\
\text { resources. }\end{array}$ \\
\hline $\begin{array}{l}\text { Hastasapoulos, Krugman, and } \\
\text { Summers }\end{array}$ & $\begin{array}{l}\text { Competitiveness is the capability of a country to balance its foreign trade while achieving } \\
\text { acceptable increases in life standards. }\end{array}$ \\
\hline Fagergerg & $\begin{array}{l}\text { The capability of a country to achieve its fundamental economic targets and growth in } \\
\text { income and employment rates, especially without having problems in its foreign trade } \\
\text { balance. }\end{array}$ \\
\hline Velloso & $\begin{array}{l}\text { It is to achieve the effectiveness standards that were achieved by other countries and to } \\
\text { increase the country's participation capacity to international markets. }\end{array}$ \\
\hline Haque & $\begin{array}{l}\text { It is a multi-dimensional concept that comprises country's export capability, effective use of } \\
\text { the production resources and natural resources, and productivity increases that ensure } \\
\text { increasing life standards in the country. }\end{array}$ \\
\hline $\begin{array}{l}\text { UNICEF (United Nations } \\
\text { International Children's Emergency } \\
\text { Fund) }\end{array}$ & $\begin{array}{l}\text { It represents increasing its life standards to a level comparable to or even higher than those } \\
\text { of developed countries, without deterioration in its external position. }\end{array}$ \\
\hline $\begin{array}{l}\text { OECD (Organization for Economic } \\
\text { Co-operation and Development) }\end{array}$ & $\begin{array}{l}\text { It is the capability of manufacturing products that are suitable to the demands and } \\
\text { expectations of the clients in the foreign countries while achieving real income increase } \\
\text { within the country. }\end{array}$ \\
\hline EU Commission & $\begin{array}{l}\text { It is the capability of countries, establishments, industries, and regions to increase their } \\
\text { incomes from production factors and to create high work force under strict competition. }\end{array}$ \\
\hline
\end{tabular}

In the last years, there is a common idea that competitiveness can be directed with government policies. The latest popular approach is to explain national economy's competitiveness through management style, including management-employee relations. The problem here is that different branches of industry require different management styles. In the same way, management-employee relations cannot be generalized either. Although there are views that the presence of strong trade unions will affect the comparative superiority in a negative manner, there are firms with international superiority in Germany and Sweden, where trade unions have strong presence.

The sole meaningful concept of competitiveness at the international level is the productivity. The duty of every country is to achieve a high level of income for its citizens. The capability of achieving this depends on whether that country can use its own man power and capital in an efficient manner or not. Productivity is measured with the value of the production achieved with every unit of manpower and capital, and it depends on both the quality and specifications of the product and the effectiveness of the production. 
Life standard in any country depends on the capacity of that country's firms to reach high levels of productivity and to increase productivity over time. An economy has to constantly renew itself in order to achieve constant productivity increase. Firms in a country can develop industrial productivity by increasing product quality, adding new features, developing production technology, or increasing production effectiveness.

International trade and foreign investment can impact a country's productivity in a constructive or threatening way. These two elements can increase a country's productivity by specializing in more productive sectors, while importing for its sectors which have less productivity. However, international trade and foreign investments can also threaten the increase in productivity. These two elements can test whether the productivity of the industries in the country is in the international standards or not. If productivity in an industry is not higher than that of foreign firms, this country will lose, even if it has manpower cost advantage. If a country loses its competitiveness in many high-productivity and high-pay industries, then the life standard of that country is under danger. Then, in order to research competitiveness of a country, we need to determine what type of characteristics do industries of that country, which has competitiveness in certain fields have. It is especially necessary to find determinants of international success in technology and skilled manpower intense industries and supporting industry branches.

Why can some firms in some countries always make innovation? Why do they constantly try to ameliorate their current situation and achieve competitive superiority in increasingly more complex issues? The answer to these questions can be found in four fundamental characteristics that every country form and operate for their own industries and that form the "competitiveness diamond" individually and collectively (see Figure 1).

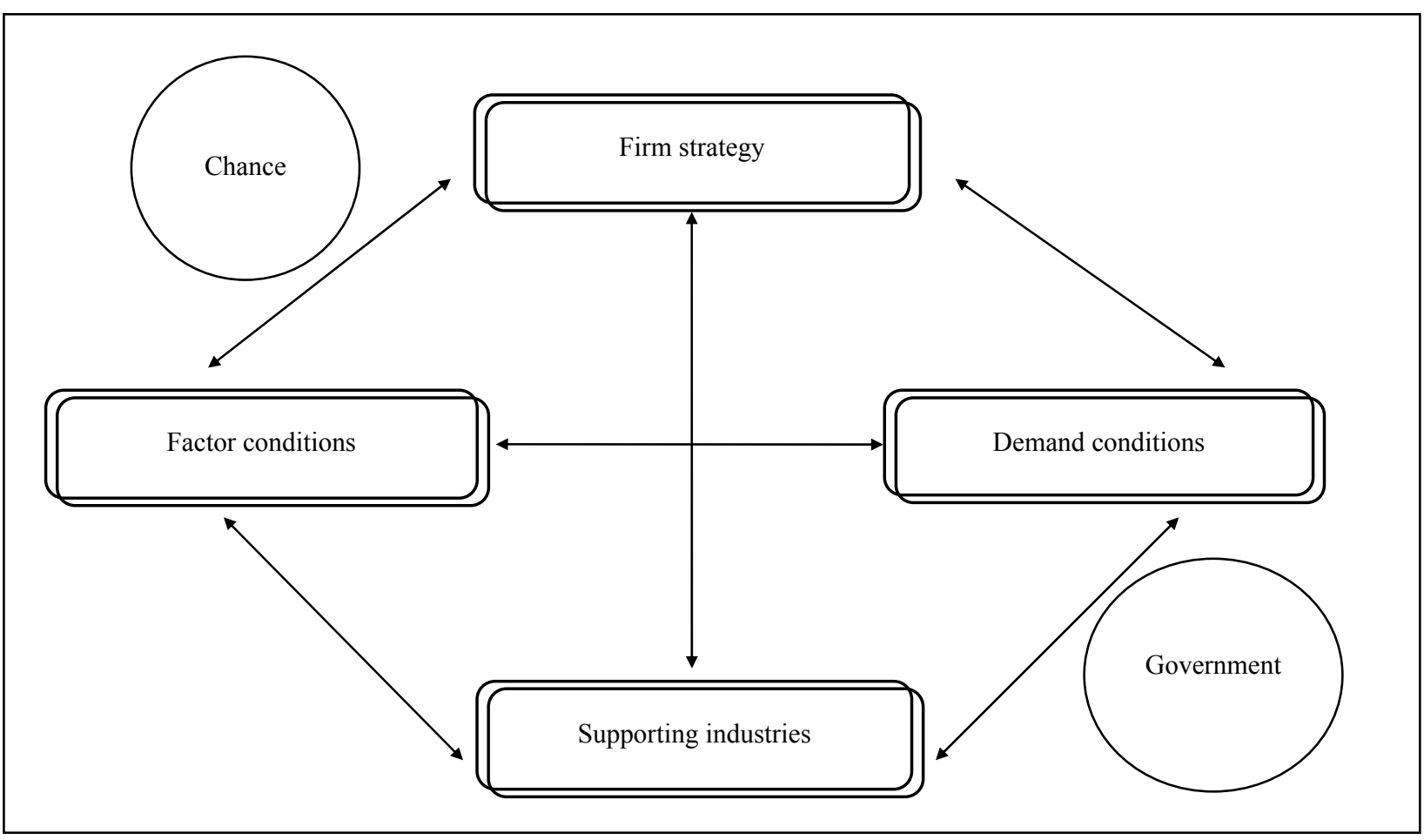

Figure 1. Competitiveness diamond. Source: Porter (1990, p. 72). 
Factor conditions: the situation of a country's production factors that achieve competition capability in certain sectors such as skilled work force or infrastructure.

Demand conditions: the structure of the domestic demand to the product or service of a certain industry within the country.

Supporting industries: presence or absence of supporting industries that have international competition capabilities within a country.

Firm strategy, structure, and rivalry: the conditions that impact the establishment, structure, management style, and domestic competition of the firms in a country.

These characteristics constitute the climate that firms are born in and learn to compete in. Every individual section in the diamond and the diamond as a whole itself impact the factors that assure international competition superiority. Among these factors are availability of resource and skilled manpower; information that shapes opportunities perceived by firms and that channels manpower through resources; objectives of firm owners, management, and employees; and above all, tendencies to invest and make innovations.

Among these factor conditions, there are two types of factors. Some of them are fundamental production factors, and others are superior production factors that essentially constitute competition. These are the factors that Turkey has ignored the most, especially through the last years.

Second is the supporting industries. For a country to be strong in the competition in international market, its industries and supporting industries need to have strong relations. For a sector to have competitiveness in international area, it needs to have well-functioning supporting sectors that provide cheap and high-technology inputs for that sector.

Another section in this diamond is demand conditions. When we analyze the countries with international competitiveness, we see that domestic demand in these countries is very sensitive.

Forth section is the firm strategy. If a country has an outward-oriented policy, the firms will have a higher success chance in terms of export. What is important here is not only the competition among firms in the country, but their competition against imported products. The firms in the country might even be oligopolistic or monopolistic. For example, there are not 20 automobile factories in any country. However, there are many German and Japanese cars with very low custom duties. Thus, American domestic automotive industry has to compete with them. This competition within the country helps the country to have competitiveness in automotive industry at the international level.

\section{Competitiveness and Entrepreneurship}

Although international competitiveness is known as an indicator that determines the competitiveness of the countries in macro-economic terms, it is in fact a concept that comparatively reveals the superiorities of micro-economic production units in terms of their competitiveness in international markets (Aktan, 1998, p. 79).

International competitiveness is defined from two different points of views in academic research: Micro-level approach analyzes competition among firms within the country and the impacts of this competition within the international market; whereas macro-level approach focuses on the position of the country in the national/international competition (Scoot \& Lodge, 1985, p. 20). 
Firm level competitiveness depends on a firm's lower cost of production compared with its competitors in domestic or global markets, its equality or superiority to its competitors in issues such as product quality and service and product attractiveness, and its innovation and invention capability.

Industrial competitiveness is the capability of an industry to reach and continue a productivity level that is equivalent or superior to its competitors or the capability to produce or sell at an equivalent or lower cost compared with its competitors.

National (international) competitiveness is "the capability of a country to increase its public real income under free and fair market conditions, while producing products and services in accordance with the international market conditions and standards".

Another important issue is to make the increase in the country's life standards sustainable under free market conditions. Many scholars state that this development depends on the amelioration of the capabilities of that country to design, produce, distribute, and market various products in international trade field (Scoot \& Lodge, 1985, p. 3).

This rapid development and change with globalization created an intense competition environment among countries and firms. Those which can benefit from this competition climate are the countries and firms that can use their entrepreneurship powers and potentials (Özpeynirci, Duman, \& Erdemir, 2006, p. 160).

Nowadays, with the impact of globalization, trade has gained an international dimension, one that reaches over the borders of any country. Production styles, management styles, and client profiles of the firms go under constant changes in the international markets. This situation forces firms to undertake new initiatives or constantly renew themselves (Tekin, 2004, p. 2).

Management and entrepreneurship methods also change with the changing social structure in the 21 st century's information society. The main reason for this is that the information, which is the main input of information society, is produced and directed by people. This change put people in the very center of socio-economic structure. Thus, information society entrepreneurs have unique characteristics.

\section{Opportunities and Threats of Global Competition on National Entrepreneurs: A SWOT Analysis}

Economic aspect of globalization gained importance especially during the 1980s. Industrial firms in the world have been widely affected because of rapid changes in markets, products, and production technologies on the one hand, and ever-increasingly heavier competition conditions on the other hand (Aydın, 2003, pp. 83-84).

In this new global set-up, the basis of the economic competition has transformed from national economies scale into global aspects (Koçdemir, 2000, p. 154). A new era, in which markets that open up to foreign markets contribute to development of world trade and increasing trade volume contributes to increase of social welfare and connect countries to each other, started.

The importance of direct investment in development has increased tremendously and national economies of countries have become more open to foreign competition than ever. The increase in number of firms that have activities abroad and that of trade activities with international dimension has caused increase in practices that disrupt the trans-border competition as well. Furthermore, due to the absence of international rules that ensure implementation of provisions in competition regulations of countries at the international level, national competition rules could not be implemented. Most of the time, the countries with competition legislation could 
not receive necessary information from places outside of their jurisdiction, and for this reason, they could not find effective solutions against trade activities that affect them negatively.

On the other hand, there are sometimes discrepancies between the policies that aim to increase (promote) international trade and competition legislation. Incentives that aim to increase exports, export agencies, or legislation for increasing exports through joint ventures can be evaluated within this framework. Although this type of legislation creates a scale advantage and export increase opportunity, it could hurt the competition environment in foreign markets through collective determination of prices and outputs. Some activities of firms, such as export cartels, which are not subject to competition rules in the national market, might have a disturbing impact in export markets as well.

National entrepreneurs have an important place in the socio-economic development of countries in intense competition climate that they face because of increasing globalization. Following SWOT (Superiority Weakness Opportunity Threats) analysis is conducted to see whether they will have positive developments in general structure of both their own countries and of world economy, and to evaluate these developments in terms of strengths, weaknesses, opportunities, and threats.

\section{Strengths of National Entrepreneurs}

(1) Strong solidarity in the firms;

(2) High motivation among employees for embracing the business;

(3) Their receptiveness to expanding to the level where they can compete in international markets;

(4) Distribution of risk by allocating manufacturing and sales capacity to domestic market during international crises;

(5) Quick adaptability to fluctuations that could occur in economic conditions of the country;

(6) Low manpower costs;

(7) The fact that they generally have equity capital based finance system;

(8) Rapid manufacturing and management mechanisms due to low level of corporate bureaucracy;

(9) Easy control over employees and high level of labor productivity due to fewer employee numbers;

(10) Creation of external factors in order to encourage entry of foreign firms;

(11) Flexibility in terms of marketing, manufacturing, and services.

\section{Weaknesses of National Entrepreneurs}

(1) Insufficiency of equity capital compared with international entrepreneurs;

(2) Failure to manufacture with high capacity as a result of insufficient equity capital;

(3) Failure to employ qualified employees due to low wages;

(4) Insufficient use of modern marketing techniques;

(5) Disregard of R\&D activities;

(6) Delay in manufacturing new goods and choice of fake good production;

(7) Insufficiency to manufacture in the global standards;

(8) Indifference to acquiring quality assurance certificates.

\section{Opportunities for National Entrepreneurs}

(1) Increase in number of institutions and agencies that will provide support for production, marketing, financial, and technological aspects; 
(2) Loan opportunities from international finance institutions;

(3) Young population in terms of entrepreneurs and employees;

(4) Willingness among foreign partners to become partners to profitable national initiatives.

\section{Threats for National Entrepreneurs}

(1) Negative impacts of fluctuations in the economy on the demand structure;

(2) Their continuous perception of international large scale presence as a threat;

(3) Increasing competition as a result of globalization;

(4) Destructive impacts of goods imported from countries which have very low cost production on domestic and global markets.

\section{References}

Aktan, C. C. (1998). Türkiye Dünyanın Neresinde (Where is Turkey in the world)? Ege Genç İşadamları Derneği (EGİAD) (Aegean Young Industrialists' Society), İzmir.

Aktel, M. (2003). Küreselleşme ve Türk Kamu Yönetimi (Globalization and Turkish public administration). Ankara: Asil Release Distribution.

Aydin, M. K. (2003). Sermayenin Küreselleşmesi “Kapitalizmin Altın Dönemi’nden Neoliberal Dalgaya Uzanan Süreç” (Globalization of capital "period from golden era of capitalism to neoliberal surges”). İstanbul: Değişim Yayınları.

Bauman, Z. (1999). Küreselleşme: Toplumsal Sonuçlar (Globalization: The human consequences). (A. Yılmaz and A. Yayınları, Trans.). İstanbul: A. Y1lmaz Yayınları.

Bayraktutan, Y. (2003). Global Ekonomide Bütünleşme Trendleri (Integration trends in global economy). Ankara: Nobel Yayınevi.

Demirel, D. (2006). Küresel Eksende Devletin Yeni Kimliği: Etkin Devlet (New identity of state in global axis: Effective state). Sayıştay Dergisi (Supreme Court of Public Accounts Journal), 60, 58. Retrieved from http://www.sayistay.gov.tr/ yayin/dergi/icerik/der60m6.pdf

Doğan, A. E. (2002). Birikimin Hamalları (Porters of accumulation). Ankara: Donkişot Yay.

Egeli, P. (2009). Globalleşme ve Küresel Kriz (Globalization and global crisis). Proceedings from EconAnadolu 2009: International Anatolian Economy Congress. June 17-19, Eskişehir.

Eren, E. (2013). Stratejik Yönetim ve İşletme Politikası (Strategic management and business policy) (p. 386). İstanbul: Beta Yayınlar1.

Ertürk, E. (1996). Ekonomik Entegrasyon Teorisi ve Türkiye'nin İçinde Bulunduğu Entegrasyonlar (Economic integration theory and integrations that Turkey is involved in). Bursa: Ezgi Kitabevi Yayınları.

Friedman, T. (2000). Lexus ve Zeytin Ağacı: Küreselleşmenin Geleceği (Lexus and the Olive Tree: Future of globalization). (E. Özsayar, Trans.). İstanbul: Boyner Holding Yayınlar.

Gökbunar, R., \& Yanikkaya, H. (2004). Etkin Devlet ve Ekonomik Gelişme (Effective state and economic development). Ankara: Odak Yayınevi.

Gündüz, A. Y. (2005). Geçmişten Günümüze Ekonomik Yönleriyle Küçük Ve Orta Büyüklükteki İşletmeler: Malatya Örneği (Small and medium sized enterprises from past to future: Malatya example). Proceedings from International "Small and Medium Sized Enterprises in the European Union Accession Process: Turkey and Similar Countries' Experiences", Conference. May 19-22, Bandırma Faculty of Economics and Administrative Sciences, Balıkesir University, Bandırma.

Koçdemir, K. (2000). Atatürk Dönemi Kültür Politikası ve Küreselleşme (Ataturk era culture policy and globalization). Türk İdare Journal, 72(429), 154.

Kürkçü, D. D. (2013). Küreselleşme Kavramı ve Küreselleşmeye Yönelik Yaklaşımlar (Globalization concept and approaches towards globalization). TOJDAC, 3(2), 2.

Özpeynirci, R., Duman, H., \& Erdemir, N. K. (2006). Girişimcilik Sürecinde Finansal Başarısızlığın Etkileri Üzerine Bir İnceleme (An analysis on impacts of financial failures in entrepreneurship process). Proceedings from International Entrepreneurship Congress. Kyrgyzstan-Turkey Manas University Publications.

Porter, M. E. (1990). The competitive advantages of nations. Harvard Business Review, 2, 72.

Scoot, B. R., \& Lodge, C. (1985). US competitiveness in the world economy. Boston: Harvard Business School Press. 
Selek, D.-F. Ç., \& Iş̧1k Maden, S. (2009). 2008 Küresel Krizinin İhracat Yapan Firmalar Üzerine Etkisi: Isparta Örneği (Impact of 2008 global crisis on export firms: Isparta example). Retrieved from http://idc.sdu.edu.tr/tammetinler/ kalkinma/kalkinma38.pdf

Sezen, S. (1999). Türkiye'de Planlama (Planning in Turkey). Ankara: Todaie Publications.

Tekin, M. (2004). Girişimcilik ve Küçük İşletme Yöneticiliği (Entrepreneurship and small sized enterprise management) (4th ed.). Konya: Detay Yayıncilik.

Yeldan, E. (2001). Küreselleşme Sürecinde Türkiye Ekonomisi: Bölüşüm, Birikim ve Büyüme (Turkish economy in the globalization process: Distribution, accumulation, and growth). İstanbul: İletişim Yayıncılık. 